\title{
Mediation: education for human rights and skills in the culture of dialogue
}

ndividualism is experiencing a period of splendour. It is a trend related to the level of economic development of a society, which is promoted, like the globalization, by the interaction so present in our society between the individual and the new technologies. And it is materialized in the consideration of the individual as an independent unit. In our day to day we find continuous messages repeating that we must learn to live. On television, in the subway, in social networks, we see them everywhere. Living appears to be easy. If we look in the Dictionary of Real Academia Española (RAE) we find different meanings: from "having life" or "dwelling or dwelling in a place or country" to, among others, "to adapt to circumstances or to take advantage of them to achieve their own conveniences." Living, we have said, sounds easy. However, we must not overlook a nuance: we do not live alone, we live in community, we live together. And, what is it to live together? We could say that it is to combine the interior of each one in the exterior of the others. This requires dialogue, empathy, sensitivity, co-responsibility. Many centuries of evolution have been necessary for the Homo sapiens. The cognitive and communicative capacity that defines us can only be arised in the gregarious being that we are. Life in community has made us what we are and only in the coexistence we live.

The human being in itself is communication and coexistence. Without these two conditions, the person becomes dehumanized. All other animals are born knowing what they need to live, and the man, on the other hand, needs to learn it. Living cannot be improvised, it requires a continuous learning that involves dialogue, solidarity and respect. But those who learn to live together learn to be a person.

* Helena Pérez Beltrán. Degree in Law. Master in Mediation and Efficient conflict management. Chair of Police Mediation City of Vila-real of the University Jaume I (Spain).E-mail:heperez@uji.es 
In 1948, after the man showed the most abject behaviours towards their counterparts in the Second World War, the 30 articles known as Human Rights were agreed upon. That ethical code of what human dignity must represent remains valid today, but its fulfilment remains a utopia. Beyond the great gestures of humanitarian action, those Rights that we write in capital letter are simply respected if we respect the other. Dialogue and coexistence are, once again, the keys to that respect. Traditional education has not emphasized the importance of educating in these values in order to promote a culture of peace. This also requires learning. Fortunately, learning is no longer exclusively associated with the early ages of life. It has been shown that learning is inherent to the development of the person and, therefore, it is also referred to as lifelong learning. Acquiring skills and procedures, is the best tool to deal with lacks.

Mediation is a procedure that has proved to be very adequate to resolve the conflicts generated by the lack of dialogue and the deterioration of coexistence. Bush and Folguer, both references of the Transformative Model of Mediation, understand that "mediation is a way of promoting a qualitative transformation of human interaction". It teaches us, in turn, to handle conflict, tensions and interpersonal relationships. We cannot articulate only with norms (with law) the interests, the needs and the divergent desires that we find in our social cosmos. Thus, once force is rejected, we need something else, we need the word. All war concludes with a negotiation but, as Josemi Valle states "force can end a conflict, but the word has the exclusive patrimony of its solution"2.

However, for the purpose we pursue we cannot make use of any word. Following the methodology of the Circular Narrative Model of mediation, proposed by the American Sarah Cobb, a good part of the mediator's job is to create a new conversation that guides people out of their conflictive situation. To create this type of conversation requires, in turn, to development of a new language, given that people who come to mediation have already defined themselves as adversaries and, therefore, they tend to produce stories or accounts of accusation, justification and reproach. The mediator has to provide words to the mediation that welcome, clarify, encourage, clean, enable, heal, respect, excuse, invite, in short, words that open doors, words that "positivize" the environment. To "positivize" is to eliminate the obstacles and the barriers through small interventions during the mediation processthat gradually transform the nuance of the conversation and the dynamics of the conflict ${ }^{3}$. To do this, the mediator must show an honest, patient, respectful, empathetic, transparent, welcoming and hopeful attitude.

${ }^{1}$ Baruch Bush R.A., y Folger J.P., La promesa de la mediación: cómo afrontar el conflicto mediante la revalorización y el reconocimiento, ed. Granica, 1996.

${ }^{2}$ Valle J., La capital del mundo es nosotros, ed. CulBucks, 2016, p. 32.

${ }^{3}$ Munduate L., Butts T., Medina F.J. y Martínez-Pecino R., Manual para la mediación laboral. Consejo Andaluz de Relaciones Laborales, 2008, p. 161. 
The mediator can make use of strategies and tools such as using constructive adjectives and appropriate words, talking about wishes and needs, asking constructive questions, recognizing the discomfort, reframing harmful comments, admitting his/her own mistakes, managing anger, facilitating recognition, and also, placing an emphasis on the future.

It is not an object of this article to review the skills and mediator's tools ${ }^{4}$, but I would like to dwell on a skill that the mediator must learn to promote the security and the effectiveness of mediation, whichis not so regularly handled in the manuals of mediation as it should be: the recognition and management of anger.

Aristotle already affirmed in Ivth century B.C. that "anyone can become angry, that is easy, but to be angry with the right person, to the right degree, at the right time, with the right way and for the right purpose, that certainly is not so simple". Along with him, other philosophers like Plato, writers like Shakespeare, and politicians like Thomas Jefferson thought that anger should be controlled and those who achieved it were called as strong and wise humans. Faced with this idea, personalities as Darwin and Freud considered that anger was a human biological trait, an automatic response that was not subject to control. Recent researches show that both camps are right, so anger is both an intense physiological process and a cognitive one ${ }^{5}$.

So we come to the conclusion that we humans cannot control what we feel but we can choose how to respond to what we feel. In this light, and based on the study of the international mediator Thelma Butts on anger management, we discuss hereinbelow those important aspects that the mediator must understand about this emotion.

First, research has proven that genetics can influence anger. This explains why we found people that are calmer and less irritable than others. The mediator must take it into account to avoid taking a negative and partial perspective with the party who may have this emotional difficulty and (must) focus on directing him/her efforts at mitigating the effects of anger in the implicated.

Second, Tavris (1989) cited by Butts (2007, p.22) offers research that explains that cognitive processes feed the physical processes, and the physical processes

${ }^{4}$ For a thorough knowledge of the tools and techniques of mediation we refer to the following manuals:

Diez F. y Gachi T., Herramientas para trabajar en mediación, Barcelona, ed. Paidós, 1999.

Baruch Bush R.A., y Folger J.P., La promesa de la mediación: cómo afrontar el conflicto mediante la revalorización y el reconocimiento, ed. Granica, 1996.

Fisher R., Ury W. y Patton B., Obtenga el sí: El arte de negociar sin ceder, Barcelona, ed. Gestión 2000, 2011.

Moore C.W., Dinámica de la mediación, Barcelona, ed. Paidós, 1995.

${ }^{5}$ Butts Griggs T., Manejando la ira en la mediación: conceptos y estrategias", Portularia, vol. VII, núm. 1-2, 2007. 
can feed the cognitive processes. Thus, the mediator must keep in mind that when people are not physically calmed, they are more likely to have angry thoughts, for example, if someone was in rush for arriving to the mediation session, or he/she has had a great shock in his/her way to the session, or he/she has even taken more caffeine thanusual, etc. In those states of excitement, a little provocation can provoke him to physical anger and wrathful thoughts. This is not trivial, because for the mere fact of attending a mediation, an unknown process in many cases in which two opposing parties will have to sit down to dialogue, the implicated frequently come to mediation feeling certain natural apprehension, nervousness or uneasiness. The same thing happens in reverse, thinking and musing can provoke a physical state of agitation that returns to fuel the wrathful thoughts that include blaming, judging, attributing bad intentions, etc. If the mediator perceives anger on one side, he must not ignore it, but to prevent its escalation and reduce the tension before returning to the purpose of mediation.

How can the mediator do it? Here we rescued the aforementioned Circular Narrative Model and positivization of language, and we add one of the premises on which the Harvard Traditional-Linear Model is based: the mediator addresses a dialogue based on interests rather than positions. When people are angry their egos identify with their positions, they discuss positions, they talk about their weapons. This, in turn, generates more anger and resentment. Instead, the mediator must reorient the conversation to the underlying interests of each party, that is, towards their real needs. This is an excellent way to open the doors to a collaborative process.

In view of the above, we also want to show that, in many occasions, it can be positive and useful to incorporate into the mediation some ideas and techniques of the different models of mediation that we have mentioned throughout this text. Although each model puts the accent on a different aspect, on achieving an agreement, or achieving the transformation of the relationship, or both at the same time, we must not forget that "people are emotion, we have emotions. We live excited"6.

Managing an emotion as intense as anger is critical in order to achieve an effective communication. The management of formulas such as the apology also responds to a process that relies on the emotions of those involved, and, surprisingly, they are increasingly used in business. We are accustomed to thinking that both apologizing and forgiveness are a practice of the mediation in the criminal field in the hand of Restorative Justice. However, as we said, more and

${ }^{6}$ Pérez Four-Pome M., "Las emociones en mediación", Revista de Mediación”, Año 3. No 5, Marzo 2010, p. 17. 
more companies are recognizing the advantages and benefits of using $\mathrm{ADR}^{7}$ methods, either to apologize or to reach agreements that avoid court proceedings. As an example of the first case, at the end of 2013, the Apple company in China apologized to the consumers of its products due to problems with the company's warranty policy, and it promised to negotiate certain conditions of their devices, rectify and review any errors resulting from this policy followed by the company ${ }^{8}$ Meanwhile, Google reached an agreement with the conflicting parties when it was accused by European and American regulators of abuse of its dominant position in online searches, while it was promoting its services, as Google Shopping, to the detriment of the services of its competitors. In recent years Google's dispute resolution strategy has combined mediation and arbitration. Given the high cost and risks involved in prosecution, Google's bargaining strategy has avoided large fines to the company, which has meant an increase in its global annual revenues ${ }^{9}$. To these concrete benefits we can add more generic but also obvious advantages: speed in the solution, discretion, confidentiality, efficiency, flexibility, ethics and maintenance of relations between the parties.

The economic benefit of using ADR methods is therefore proven. And although it is not so easily quantifiable, their social benefit is also recognized. They represent an advance in the culture of dialogue, in education for coexistence and in peace. Although it is the family who educates, it is also up to the teaching plans to enhance social and communication skills, the culture of dialogue and the ethics of coexistence from primary and secondary education. It is a learning to change our response mechanisms, which potentiates a pre-reaction reflection

7 ADR stands for Alternative Dispute Resolution, a generic term that refers to the resolution of conflicts between two parties through the intervention of a third party that helps them to manage and resolve their dispute without resorting to judicial process. The most widely used terms within the ADR category are, explained in a generic and succinct way, the followings: negotiation, understood as the activity tending to approach the positions of the opposing parties through an exchange of proposals and concessions until reaching a agreement that satisfies both; conciliation, a method of conflict resolution through which the parties request the intervention of a third party that will promote formulas of agreement, without delegating the solution in it, that will allow them to reach satisfactory agreements for both parties; mediation, understood as a structured procedure in which a neutral and impartial third party facilitates communication so that the parties can resolve their own conflict; arbitration, a procedure by which the parties submit the decision of their dispute to a third party who is an specialist in the matter, who can act as a single or multiple-member arbitrator and whose decision, the so-called arbitral award, must be complied; and collaborative law, the most common channel in the negotiation of conflicts of separation and marriage divorce in the United States, through which the parties voluntarily negotiate, with the legal assistance of their lawyers, the issues arising from their marriage rupture, without prejudice to other professionals attend the proceedings.

${ }^{8}$ https://www.pon.harvard.edu/daily/international-negotiation-daily/top-10-international-negotiations-of-2013-apples-apology-in-china/

${ }^{9}$ https://www.pon.harvard.edu/daily/dispute-resolution/googles-approach-to-dispute-resolution/?mqsc $=$ W3841237 
in potentially dangerous situations, which teaches us to think twice about the small things that can turn into fights or explosive attitudes. As W. Ury, representative of the Harvard Traditional-Linear Model, noted: „We taught them to ask: 'Did you step on me on purpose? Is that a good reason to fight, to endanger my goals?"'10. As the territory of possibility is inexhaustible, we want to think that it is possible that someday children will receive a global education in the recognition and the management of emotions such as anger, and in problem management and resolution. „Just as physical education has become a normal part of the curriculum, social-emotional education may soon follow"11.

Education in civic and ethical values is also a step in the same path of understanding the individual in society. "The difficulty of instilling immaterial values in a world fascinated by material goods"12 is undeniable, but, as Aristotle prescribed, ethical virtues can only be acquired through the habit. The periods of economic crisis also put the values of a society in crisis, and the special virulence of the crisis that began in 2007 has undermined the myth of continuous progress. For the first time individuals know that the children do not live or will not live better than the parents. But in difficult and contradictory times it is still possible to give ethical reasons for hoping for a better future. We could say that hope depends on what we cultivate. Cultivate and culture come from the same Latin term. All cultures have faced the same problems (surviving, coexisting, organizing coexistence, etc.) but each of them has faced them differently. We must understand the problems and show that there are better and worse solutions. It is up to us to decide with our behaviour and our decisions what solutions we prefer to promote. An education that takes into account the implicit values in mediation stimulates respect and tolerance towards the other, peaceful coexistence, consensus, dialogue and word.

Giving preference to over-educated education, it is no longer a mistake for the education system. We learn means and techniques, but we forget the ends. And the noblest purpose of education is to teach us to treat others with the same consideration that we demand for ourselves; to feel the other as an extension of ourselves $^{13}$. It is disconcerting the desire to underestimate the impact of others in our lives. Aristotle already verified that the others are inalienable for the person that we are and abbreviated this certainty in the well-known expression ,the man is by natural a political animal". We must not forget our choral condition, that we are beings designed with a life to be shared.

${ }^{10}$ Ury W., Alcanzar la paz. Resolución de conflictos y mediación en la familia, el trabajo y el mundo. Barcelona, ed. Paidós, 2005, p. 140.

11 Ibíd, p. 141.

12 Camps V. (2008) cited by Valle J. (2016, p. 97).

13 Valle J., La capital del mundo es nosotros, ed. CulBucks, 2016, p. 106-7. 
„The true Gordian knot of coexistence - not survival - lies in the principles of comprehensiveness, plurality and democratic participation"14. Mediation promotes comprehensibility by giving the same prominence to all those involved in a conflict; defends plurality by listening and accepting all versions of reality; and contributes to democratic participation by encouraging people to take responsibility for their conflicts and freely make decisions and commitments that they consider most satisfactory to all. Mediation affect the capabilities of each person and community to overcome differences and to approach positions, it seeks to move from a culture of confrontation and strife to another based on dialogue and respect, and it entails a re-reading of interpersonal relations from the language of the consensus and the culture of peace.

The United Nations defines the Culture of Peace „as a set of values, attitudes, behaviours and lifestyles that reject violence and prevent conflicts by tackling their roots through dialogue and negotiation between individuals, groups and States”. And in their "Declaration and Program of Action on a Culture of Peace" (1999), they recognized in their introduction: "that peace not only is the absence of conflict, but also requires a positive, dynamic and participatory process where dialogue is encouraged and conflicts are solved in a spirit of mutual understanding and cooperation".

It is evident, then, that after the historical trajectory that we have lived in Europe in the twentieth century, regardless of our location in the world, in the midst of the 21st century it becomes necessary to strengthen those methodologies that allow us to transit from a culture of discord and the struggle against a culture of dialogue, collaboration, respect and, ultimately, peace.

Conflicts that damage interpersonal relationships are often managed through acts that violate the dignity and rights of others. Therefore, to educate in mediation is to educate in values that make possible the cooperation, the peaceful coexistence and the respect to the fundamental rights of the people.

In the light of these principles and the proven progress and social benefits that it represents, we believe that effective measures should be taken at the political level and by the Administrations to accelerate the process of implementation of mediation as far as possible.

We pretend to flee from a simplistic approach of mediation that leads to consider it as an alternative route to the judicial path. In any case, it should be seen as complementary to it. But mediation is not only a fast and economic way and a method that decongests the courts. If only that, we would have found „a formula to metamorphose the form but not the bottom of our litigating

${ }^{14}$ Boqué M.C., Cultura de mediación y cambio social, Barcelona, ed. Gedisa, 2003, p. 10. 
societies, or what is the same, a way of changing to remain the same"15. Nor is it just a simple technique of management or resolution of conflicts. It is much more, since mediation contains innumerable values that flood everyone who comes into contact with it. We are referring to a cultural conception of mediation, which is why it is a much more complex practice than it may seem at first glance.

\section{Bibliography:}

Baruch Bush R.A., y Folger J.P., La promesa de la mediación: cómo afrontar el conflicto mediante la revalorización y el reconocimiento, ed. Granica, 1996.

Boqué M.C., Cultura de mediación y cambio social, Barcelona, ed. Gedisa, 2003.

Munduate L., Butts T., Medina F.J. y Martínez-Pecino R., Manual para la mediación laboral. Consejo Andaluz de Relaciones Laborales, 2008, p. 161.

Pérez Four-Pome M., "Las emociones en mediación", Revista de Mediación, Año 3. № 5, Marzo 2010. Ury W., Alcanzar la paz. Resolución de conflictos y mediación en la familia, el trabajo y el mundo. Barcelona, ed. Paidós, 2005.

Valle J., La capital del mundo es nosotros, ed. CulBucks, 2016.

\section{Summary:}

Mediation is proving to be an effective way to manage conflicts in a constructive way. But mediation not only helps to solve specific problems, because its potential encompasses aspects of greater complexity. Thus, mediation helps us to know ourselves better, to better understand others, and to use what we have learned to better manage future conflict situations. In a society where there is no culture of agreement and where there is no education in the field of emotions, mediation becomes an adequate and effective tool to resolve conflicts in a peaceful and constructive manner.

On the other hand, mediation allows the parties to take responsibility for the resolution of their own conflict, to be active agents in the process. The greater the citizens' participation in the different decision making processes, the more democratic a society will be. That is why, in the restoration of social peace, citizenship should play a role as an active agent, and mediation is a suitable instrument for this purpose because the individuals in conflict find the way to solve it without third party impositions.

Keywords: mediation, culture of dialogue, coexistence, values.

${ }^{15}$ Ibíd. 